\title{
Terrestrial impact structures as geoheritage: an assessment method of their scientific value and its application to Brazil
}

\author{
JOANA P. SÁNCHEZ ${ }^{1}$ and JOSÉ B.R. BRILHA ${ }^{2}$ \\ ${ }^{1}$ Science and Technology Faculty, Geology, Federal University of Goiás, Rua Mucuri, s/n, \\ Área 03, Setor Conde dos Arcos, 74968-755 Aparecida de Goiânia, GO, Brazil \\ ${ }^{2}$ Institute of Earth Sciences, Pole of the University of Minho, Campus de Gualtar, 4710-057 Braga, Portugal
}

Manuscript received on February 21, 2016; accepted for publication on October 28, 2016

\begin{abstract}
Terrestrial impact structures are geological and geomorphological features with particular importance to understand the history and evolution of the planet. Impact structures are scattered around the world but in many countries these features are under threat, essentially due to anthropic factors. Impact structures with higher scientific value should be considered as geological heritage and, consequently, be subjected to geoconservation strategies. In order to select the most important impact structures to be properly conserved and managed, this paper proposes a quantitative assessment method of the scientific value of these structures. The eight Brazilian impact structures were used to test this method that has the potential to be applied to any geological context in any country. The structures known as Araguainha Dome-MT and Serra da Cangalha-TO reached a higher scientific value, which justifies the need to develop geoconservation strategies and a proper management.
\end{abstract}

Key words: geological heritage, impact structure, assessment, inventory, geoconservation, Brazil.

\section{INTRODUCTION}

Studies and protection initiatives on geological heritage have been expanding all over the world in order to conserve particular geodiversity elements that are important for the understanding of Earth's origin and evolution. Besides the scientific value, geoheritage may also have other types of values, which constitute the bases for its sustainable use with educational, recreation, and tourism activities at national and local levels (Brilha 2016 and references herein). The identification of geological

Correspondence to: Joana Paula Sanchez

E-mail: joana_paula_sanchez@yahoo.com.br sites should be based on solid scientific criteria, which take into account the need to select really meaningful geodiversity exemplars that are truly relevant to understand the geological history of planet Earth. It is geoscientists' responsibility to select the most relevant elements of geodiversity in order to demand from managers its proper conservation and management.

Geoconservation - the identification, conservation, and management of exceptional occurrences of geodiversity - is of extreme importance for the study of Earth's environmental and life evolution (Henriques et al. 2011, Prosser et al. 2011, Brilha 2015, 2016, Henriques 2015). 
This evolution has been affected by the occurrence of certain phenomena, some of them with a global effect. The impact of extraterrestrial bodies is exactly one of these phenomena that has greatly contributed to major changes in the Earth's surface, its life-support systems and, consequently, in life itself. Hence, impact structures are geological and geomorphological elements with high scientific importance.

Terrestrial impact structures are well known by the scientific community. In recent years, the research done in several countries showed that mineralogical, petrological, and structural evidences are determinant to identify impact structures, particularly when the typical crater landform is no longer very clear due to continuous weathering and erosion.

The main objective of this work is to propose a method to allow the inventory and quantitative assessment of impact structures, aiming their conservation and management as geosites with scientific value. This method can be easily applied to any type of impact structure in any type of geological setting. Despite the existence of several approaches to support the inventory and assessment of geoheritage, there are several particularities when considering impact structures as geosites. This is the main justification for the development of the method presented in this work, which application is exemplified with impact craters located in Brazil. This paper does not present or discuss elementary concepts concerning impact structures as it takes into account that readers are familiar with the science related to these features.

\section{QUANTITATIVE ASSESSMENT OF IMPACT STRUCTURES}

Theneed for a quantitative assessment of geoheritage is twofold: it aims to decrease the subjectivity associated with any evaluation procedure, and it helps to define management priorities. Sites with higher value and higher degradation risk should be given top priority for conservation.

Usually, quantitative methods of geoheritage are based on several criteria and respective indicators to which different scores or parameters may be assigned. Although there are already several methods (for example, Cendrero 1996a, b, Coratza and Giusti 2005, Pralong and Reynard 2005, Pereira et al. 2007, Reynard et al. 2016, Bruschi and Cendrero 2009, Reynard 2009, Pereira and Pereira 2010, 2012, Bruschi et al. 2011, Fassoulas et al. 2012, Bollati et al. 2013, Brilha 2016) there is a need to define new specific criteria to be applied to impact structures. These new criteria must be adapted to the genetic processes that build meteorite impact structures. In addition, in order to evaluate the scientific value, the occurrence of the largest possible number of features (microscopic, macroscopic, and megascopic) that may prove the origin of the impact structure must be considered. In general, a high diversity and quality of these features is related with a high scientific value of the impact structure. This assumption is what supports the assessment method presented in this work.

As impact structures may combine several types of geodiversity elements (minerals, rocks, deformation structures, and landforms) and at different scales (microscopic, macroscopic and megascopic), they should be considered as a complex area geosites type, according to FuertesGutiérrez and Fernández-Martínez(2010). Complex areas geosites have a physiographic homogeneity and are composed of other types of sites, such as points, sections, areas, and/or viewpoints. Due to the large area of this type of geosite, the risk of degradation of the whole structure is quite low but this risk for individual sites that together justify the scientific relevance of the whole geosite might be quite high.

The procedure for the general assessment of impact structures proposed in this work is based in three successive steps: i) inventory of sites (usually 
points, areas and viewpoints) representing the most significant scientific elements that, when considerer together, validate the origin of the impact structure; ii) quantitative evaluation of the scientific value of the whole geosite; iii) quantitative evaluation of the potential educational and touristic uses and risk of degradation for the individual sites that constitute the geosite. The results obtained in these three steps (described in the next three sub-sections) provide complete information to better support the decision of nature conservation and land-use managers.

\section{INVENTORY OF GEOLOGICAL SITES}

In order to be sure that an impact structure is really the result of a collision episode, different features should be observed. These features may be of geomorphological (uplifted crater rim or central uplift), mineralogical (coesite, stishovite, diaplectic glass), petrological (polymictic and monomictic breccias, pseudotachylite), textural (planar deformation features, shatter cones, kink bands, feather features...), and structural (folds, faults, fractures...) nature. The inventory of geological sites associated with impact structures intends to identify the best occurrences of these different types of features that contribute to better justify the scientific value of the whole impact structure as a complex area geosite. The selection of sites should be based on four criteria (Brilha 2016):

i) Representativeness - concerning the appropriateness of a site to illustrate a geological process or feature that brings a meaningful contribution to the understanding of the impact structure;

ii) Integrity - related to the present conservation status of the site, taking into account both natural processes and human actions;

iii) Rarity - number of sites in the area of the impact crater presenting similar geological features;

iv) Scientific knowledge - based on the existence of scientific data already published about the site.
The selection of sites that justify the scientific value of an impact crater should highlight rare occurrences that better represent a certain geological material or process, together with the best possible conservation status and significant scientific data already published.

\section{EVALUATION OF THE SCIENTIFIC VALUE}

The general evaluation procedure here presented is based on the method proposed by Brilha (2016). For the quantitative evaluation of the scientific value of impact structures, new criteria were considered, taking into account the geomorphological characteristics of these structures and specific macroscopic and microscopic features (Table I). The evaluation of the scientific value of impact structures is made for the whole geosite because its overall value is the result of the occurrence of a set of individual geological elements.

The final scientific value of an impact structure is a weighted sum of five criteria (Table II): size of the impact crater; diversity of megascopic and macroscopic elements; diversity of microscopic elements; integrity; and scientific knowledge. The distribution of weights by the several criteria is still a source of discussion among researchers. For the moment, this distribution is done by each researcher taking into account the relative importance of each criterion for what is being assessed. It is expected that the scientific community reaches a consensus in the near future regarding this distribution of weights. It was considered that the size of the impact crater (30\%) and the diversity of megascopic and macroscopic elements (40\%) are the two most important criteria to assess the scientific value of impact structures. The choice of these two criteria is due to the fact that: i) the larger the craters the less frequent they are; and ii) the more diversity of elements they have the better the impact origin is validated. 
TABLE I

Criteria, indicators, and parameters used for the quantitative assessment of the scientific value of impact structures. The indicators concerning criteria $A$ and $D$ are different taking into account the intrinsic characteristics of simple and complex craters.

\section{A. Size of impact crater}

The diameter is one of the main characteristics of an impact crater

\begin{tabular}{lr} 
More than $40 \mathrm{~km}$ (in case of complex craters) or more than $4 \mathrm{~km}$ (in case of simple craters) & 5 \\
$20-40 \mathrm{~km}$ (in case of complex craters) or $3-4 \mathrm{~km}$ (in case of simple craters) & 4 \\
$12-20 \mathrm{~km}$ (in case of complex craters) or $2-3 \mathrm{~km}$ (in case of simple craters) & 3 \\
$4-12 \mathrm{~km}$ (in case of complex craters) or $1-2 \mathrm{~km}$ (in case of simple craters) & 2 \\
Less than $4 \mathrm{~km}$ (in case of complex craters) or less than $1 \mathrm{~km}$ (in case of simple craters) & 1 \\
\hline
\end{tabular}

\section{B. Diversity of megascopic and macroscopic elements}

The simultaneous occurrence of different geological and geomorphological features increases the overall scientific value because it allows a better understanding of the crater's genetic processes

Occurrence of more than five types of elements (circular crater and uplifted rim, visible central uplift, shatter cones, polymictic and monomictic breccias, folds, and faults)

Occurrence of five types of elements

(1)

Occurrence of four types of elements

Occurrence of three types of elements 2

Occurrence of two types of elements

\section{Diversity of microscopic elements}

The occurrence of different geological elements such as coesite, planar deformation features, pseudotachylites, kink bands, feather features, and impact melts increases the overall scientific value because it allows a better understanding of the crater's genetic processes

Occurrence of coesite and planar deformations features 5

Occurrence of coesite or planar deformations features 4

Occurrence of these four elements: pseudotachylite, kink bands, feather features, and impact melts 3

Occurrence of three elements out of four: pseudotachylite, kink bands, feather features, and impact melts 2

Occurrence of two elements out of four: pseudotachylite, kink bands, feather features, and impact melts 1

\section{Integrity}

Conservation status of main geological and geomorphological elements

\section{D.1. Crater rim}

Very well preserved and with a circular shape 5

Well preserved but without a complete circular shape 3

Still visible but only in small portions 1

D.2. Central uplift (in case of complex craters)

Very well preserved

Well preserved but not complete 3

Still visible but just in small portions $\quad 1$ 
TABLE I (continuation)

\begin{tabular}{|c|c|}
\hline \multicolumn{2}{|l|}{ D.3. Impact breccias } \\
\hline The breccias are very well preserved & 5 \\
\hline The breccias are still visible & 3 \\
\hline The breccias are highly weathered or damaged & 1 \\
\hline \multicolumn{2}{|l|}{ D.4. Shatter cones } \\
\hline The shatter cones are very well preserved & 5 \\
\hline The shatter cones are still visible & 3 \\
\hline The shatter cones are highly weathered or damaged & 1 \\
\hline \multicolumn{2}{|l|}{ E. Scientific knowledge } \\
\hline $\begin{array}{l}\text { There are more than two papers about the geological/geomorphological elements associated with the } \\
\text { impact structure published in international journals }\end{array}$ & 5 \\
\hline $\begin{array}{l}\text { There is at least one } \mathrm{PhD} \text { thesis about the geological/geomorphological elements associated with the } \\
\text { impact structure }\end{array}$ & 4 \\
\hline $\begin{array}{l}\text { There is at least one paper about the geological/geomorphological elements associated with the impact } \\
\text { structure published in international journals or more than three papers published in national journals }\end{array}$ & 3 \\
\hline $\begin{array}{l}\text { There is at least one master dissertation about the geological/geomorphological elements associated with } \\
\text { the impact structure }\end{array}$ & 2 \\
\hline $\begin{array}{l}\text { There are at least three abstracts about the geological/geomorphological elements associated with the } \\
\text { impact structure presented in scientific events }\end{array}$ & 1 \\
\hline
\end{tabular}

\section{TABLE II}

Weights for the different criteria used for the assessment of the scientific value of impact structures. Criterion D is the arithmetic mean of D1, D2, D3, and D4 for complex craters and of D1, D3, and D4 for simple craters.

\begin{tabular}{lc}
\hline \multicolumn{1}{c}{ Criteria } & Weight (\%) \\
\hline A. Size of the impact crater & 30 \\
B. Diversity of megascopic and & 20 \\
macroscopic elements & 20 \\
C. Diversity of microscopic elements & 15 \\
D. Integrity & 15 \\
E. Scientific knowledge & 100 \\
Total & \\
\hline
\end{tabular}

EVALUATION OF THE DEGRADATION RISK AND POTENTIAL FOR EDUCATIONAL AND TOURISTIC USES

For the establishment of management priorities of geosites it is very important to know the risk of degradation based on the fragility and vulnerability of the geological elements, besides the scientific value and type of compatible uses. Brilha (2016) presents a method to evaluate the degradation risk and the potential of a geological site for educational and touristic uses.

The evaluation of the degradation risk is supported by five criteria: deterioration of geological elements; proximity to areas/activities with potential to cause degradation; legal protection; accessibility; and density of population.

According with the same author, the potential educational use assessment is based on 12 criteria: vulnerability; accessibility; use limitations; safety; logistics; density of population; association with other values; scenery; uniqueness; observation conditions; didactic potential; and geological diversity. With the exception of the last two criteria, the assessment of the potential touristic use is made with the all other criteria, to which should be added three others: interpretative potential; economic level; and proximity of recreational areas. 
Concerning impact structures, the assessment of the degradation risk and of the potential for educational and touristic uses should be made for each one of individual sites that were inventoried in the whole area of the impact structure. These assessments are not detailed here because they are out of the scope of this paper.

\section{ASSESSMENT OF THE SCIENTIFIC VALUE OF BRAZILIAN IMPACT STRUCTURES}

The above described method for the assessment of the scientific value of impact structures was tested with Brazilian structures. Eight impact craters are presently confirmed in Brazil (Figure 1 and Table III) and several other structures still require conclusive studies (Crósta 2012, KazzuoVieira et al. 2012, Maziviero et al. 2012, Sánchez 2006, 2014, Vasconcelos et al. 2012, Riccomini and Turcq 2004, Oliveira et al. 2014). The results are presented in Table IV and in figures 2 and 3.

The numerical results are in agreement with the general consensus of the national scientific community, which is a good guarantee about the accuracy of the method. Araguainha dome and Serra da Cangalha are the two impact structures with higher scientific value. These results are easily justified because:

i) Araguainha Dome has a $40 \mathrm{~km}$ diameter crater and there is the occurrence of five types of megascopic and macroscopic elements, at least three types of microscopic elements, good integrity of the majority of these elements, and several papers published in international journals;

ii) Serra da Cangalha presents a high diversity of megascopic and macroscopic elements and a high integrity of the majority of these elements (there are no in-situ shatter cones and the impact breccias are not completely preserved). The complete inventory of representative sites in each one of these impact structures is in progress.
When concluded, the risk of degradation and the potential for educative and touristic uses will be assessed for each site, which will complete the whole characterization of the Brazilian impact structures.

\section{CONCLUSIONS}

Impact structures are geological and geomorphological features with high scientific relevance and with a worldwide distribution. In spite of the fact that some of these structures are located in remote areas and consequently with few threats, many other structures are under pressure, mainly due to anthropic activities such as urban development. This is the reason why it is important to rank the impact structures according to the scientific value. In addition, this ranking provides a solid justification for the establishment of management priorities.

The existing methods for the quantitative assessment of the scientific value of geosites are not fully adapted to impact structures. The particular characteristic of impact structures is due to the fact that the overall scientific value of an impact structure is directly related with the occurrence of geomorphological and geological features under different scales (microscopic, macroscopic, and megascopic). Therefore, the determination of the overall scientific value of the whole impact structure is the sum of small sites with individual occurrences. Each site alone has just a moderate interest but when in association with all the other sites where complementary features are cropping out, the final scientific value of the impact structure can be better calculated, i.e. it is the assemblage of sites that is particularly relevant.

Concerning the geoconservation of impact structures in Brazil, it is now necessary to conclude the inventory of individual sites in Araguainha structure (the one with highest scientific value). After the conclusion of this inventory, sites should 
TABLE III

Main characteristics of impact structures occurring in Brazil.

\begin{tabular}{ccccc}
\hline $\begin{array}{c}\text { Name of the impact } \\
\text { structure }\end{array}$ & State & Type of crater & Diameter (km) & Geological context \\
\hline Araguainha Dome & Mato Grosso & Complex & 40 & Paraná Basin \\
Serra da Cangalha & Tocantins & Complex & 13 & Parnaíba Basin \\
Vargeão Dome & Santa Catarina & Complex & 12,4 & Paraná Basin \\
Vista Alegre & Paraná & Complex & 9,5 & Paraná Basin \\
Santa Marta & Piaúi & Complex & 10 & Parnaíba Basíba Basin \\
Riachão & Maranhão & Complex & 4,2 & Paraná Basin \\
Cerro do Jarau & Rio Grande do Sul & Simple & 8 & Ribeira Complex \\
Colônia & São Paulo & Simple & 3,6 &
\end{tabular}

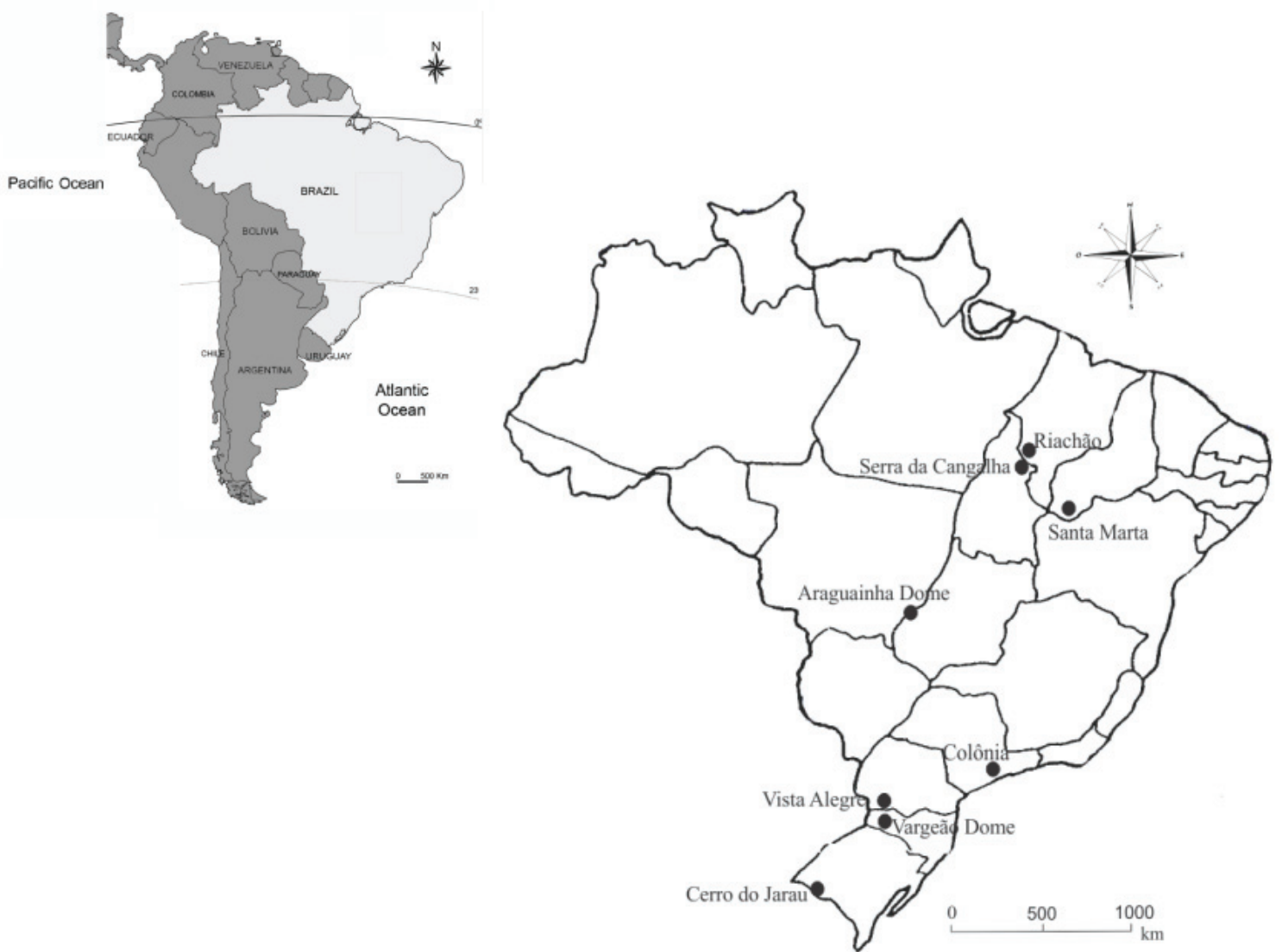

Figure 1 - General location of confirmed impact structures in Brazil. 
TABLE IV

Scientific value (SV) of the eight impact structures in Brazil and evaluation results for the five criteria (also represented in figures 2 and 3).

\begin{tabular}{cccccccc}
\hline Impact structure & State & $\begin{array}{c}\text { Criteria } \\
\text { A }\end{array}$ & $\begin{array}{c}\text { Criteria } \\
\text { B }\end{array}$ & $\begin{array}{c}\text { Criteria } \\
\text { C }\end{array}$ & $\begin{array}{c}\text { Criteria } \\
\text { D }\end{array}$ & $\begin{array}{c}\text { Criteria } \\
\text { E }\end{array}$ & SV \\
\hline Araguainha Dome & Mato Grosso & 4 & 5 & 4 & 5 & 5 & 4,5 \\
Serra da Cangalha & Tocantins & 3 & 5 & 4 & 4 & 5 & 4,05 \\
Riachão & Maranhão & 1 & 1 & 4 & 1,25 & 4 & 2,08 \\
Vargeão Dome & Santa Catarina & 3 & 4 & 4 & 4,5 & 4 & 3,77 \\
Vista Alegre & Paraná & 2 & 3 & 4 & 4,5 & 4 & 3,27 \\
Santa Marta & Piaú & 2 & 4 & 4 & 4 & 5 & 3,55 \\
Colônia & São Paulo & 4 & 1 & 0 & 0,66 & 4 & 2,1 \\
Cerro do Jarau & Rio Grande do Sul & 5 & 1 & 1 & 1 & 5 & 2,8 \\
\hline
\end{tabular}

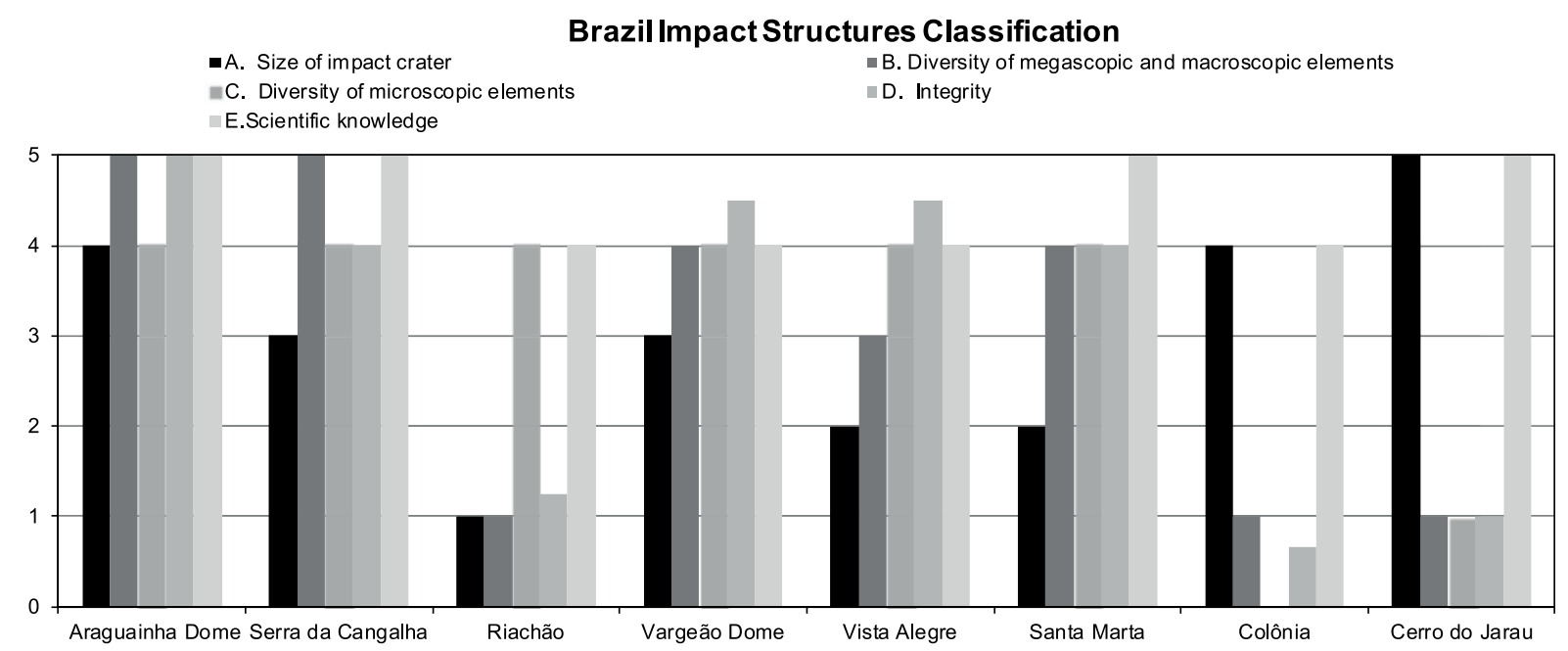

Figure 2 - Graphical representation of the results of the five criteria assessment for Brazilian impact structures.

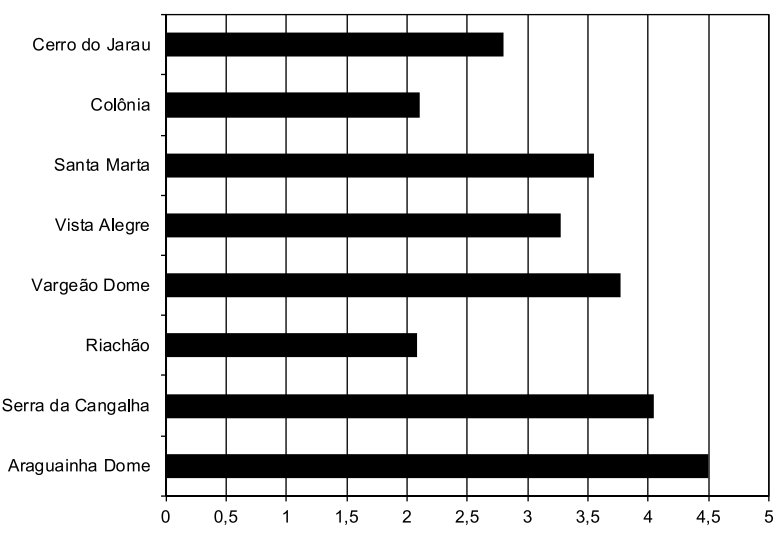

Figure 3 - Graphical representation of the scientific value of impact structures in Brazil. be assessed for their degradation risk and potential for educational and tourist uses. This assessment will be a powerful tool for management purposes and to select the best sites suitable to have a public use.

Finally, the use of the proposed method for the assessment of the scientific value of impact structures may be applied worldwide. This method may be of extreme importance when is necessary to make international comparisons between different occurrences. For instance, the acceptance of properties to be included in the UNESCO's World 
Heritage List is based on the so-called Outstanding Universal Value, which evaluation is made with a global comparative analysis supported on solid quantitative assessment methods like the one proposed in this work.

\section{ACKNOWLEDGMENTS}

The Conselho Nacional de Pesquisa e Desenvolvimento (CNPq / National Council for Research and Development) and the Programa Ciências sem Fronteiras / Science Without Borders Programme are acknowledged for the support of the postdoctoral grant No 233209/2013-1 of the $1^{\text {st }}$ author. The work was co-funded by the European Union through the European Regional Development Fund, based on COMPETE 2020 (Programa Operacional da Competitividade e Internacionalização), project ICT (UID/ GEO/04683/2013) with reference POCI-01-0145FEDER-007690 and Portuguese funds provided by Fundação para a Ciência e Tecnologia.

\section{REFERENCES}

BOLLATI I, SMIRAGLIA C AND PELFINI M 2013. Assessment and selection of geomorphosites and trails in the Miage Glacier Area (Western Italian Alps). Environ Managem 51(4): 951-967.

BRILHA J. 2015. Concept of geoconservation. In: Tiess G, Majumder T and Cameron P (Eds), Encyclopedia of Mineral and Energy Policy, Springer-Verlag Berlin Heidelberg, p. 1-2.

BRILHA J. 2016. Inventory and quantitative assessment of geosites and geodiversity sites: a review. Geoheritage 8(2): 119-134.

BRUSCHI VM AND CENDRERO A. 2009. Direct and parametric methods for the assessment of geosites and geomorphosites. In: Reynard E, Coratza P And RegoliniBissig G (Eds), Geomorphosites. Verlag Dr. Friedrich Pfeil, München. Section II, p. 73-88.

BRUSCHI VM, CENDRERO A, AND ALBERTOS JAC. 2011. A statistical approach to the validation and optimisation of geoheritage assessment procedures. Geoheritage 3(3): 131-149.

CENDRERO A. 1996a. El patrimonio geológico. Ideas para su protección, conservación y utilización. In: El patrimonio geológico. Bases para su valoración, protección, conservación y utilización. Serie Monografías del Ministerio de Obras Públicas, Transportes y Medio Ambiente. Ministerio de Obras Públicas, Transportes y Medio Ambiente, Madrid, p. 17-27.

CENDRERO A. 1996b. Propuestas sobre criterios para la clasificación y catalogación del patrimonio geológico. In: El patrimonio geológico. Bases para su valoración, protección, conservación y utilización. Serie Monografías del Ministerio de Obras Públicas, Transportes y Medio Ambiente. Ministerio de Obras Públicas, Transportes y Medio Ambiente, Madrid, p. 29-38.

CORATZA P. AND GIUSTI C. 2005. Methodological proposal for the assessment of scientific quality of geomorphosites. II Quaternario, Italien Jou. of Quat. Sciences 18(1): 307-313.

CRÓSTA AP. 2012. Estruturas de Impacto e Astroblemas Brasileiros. In: Carneiro CDR, Hasui Y, Bartorelli A and Almeida FFM (Eds), Geologia do Brasil. Ed. Beca, SP, p. 673-768.

FASSOULAS C, MOURIKI D, DIMITRIOU-NIKOLAKIS P AND ILIOPOULOS G. 2012. Quantitative assessment of geotopes as an effective tool for geoheritage management. Geoheritage 4(3): 177-193.

FUERTES-GUTIÉRREZ I AND FERNÁNDEZMARTÍNEZ E. 2010. Geosites inventory in the Leon Province (Northwestern Spain): A tool to introduce geoheritage into regional environmental management. Geoheritage 2(1-2): 57-75.

HENRIQUES MH, PENA DOS REIS R, BRILHA J AND MOTA TS. 2011. Geoconservation as an emerging geoscience. Geoheritage 3(2): 117-128.

HENRIQUES MH. 2015. Geoconservation policy. In: Tiess G, Majumder T and Cameron P (Eds), Encyclopedia of Mineral and Energy Policy, Springer-Verlag Berlin Heidelberg, 3 p.

KAZZUO-VIEIRA C, CRÓSTA AP, PITARELLO L, KOEBERL C AND KENKMANN T. 2012. Geology and impact features of Vargeão Dome, southern Brazil. Meteor Planet Science 47(1): 51-71.

MAZIVIERO M V, VASCONCELOS MAR, GÓES AM, CRÓSTA AP AND REIMOLD WU. 2012. The Riachão Ring Impact Structure, Northeastern Brazil: Re-evaluation of it is stratigraphy and evidence for impact, , CD-ROM, 43rd Lunar and Planetary Science Conference, The Woodlands, Texas. LPI Contribution No. 1659, id. 1511.

OLIVEIRA GJG, VASCONCELOS MAR, CRÓSTA AP, REIMOLD WU, GÓES AM AND KOWITZ A. 2014. Shatter cones and planar deformation features confirm Santa Marta in Piauí State, Brazil, as an impact structure. Meteor Plan Science 49(10): 1915-1928.

PEREIRA P AND PEREIRA DI. 2010 Methodological guidelines for geomorphosite assessment. Géom Relief Proc Environ 2: 215-222. 
PEREIRA P AND PEREIRA DI. 2012. Assessment of geosites tourism value in geoparks: the example of Arouca Geopark (Portugal). Proceedings of the $11^{\text {th }}$ European Geoparks Conference, Arouca, p. 231-232.

PEREIRA P, PEREIRA DI, AND ALVES MIC. 2007. Geomorphosite assessment in Montesinho Natural Park (Portugal). Geog. Helvetica 62: 159-168.

PRALONG JP AND REYNARD E. 2005. A proposal for the classification of geomorphological sites depending on their tourist value. Quate 18(1): 315-321.

PROSSER CD, BRIDGLAND DR, BROWN EJ, LARWOOD JG. 2011. Geoconservation for science and society: challenges and opportunities. Proc Geol Assoc 122(3): 337-342.

REYNARD E. 2009. The assessment of geomorphosites. In: Reynard E, Coratza P and Regolini-Bissig G (Eds), Geomorphosites, Verlag Dr. Friedrich Pfeil, Munchen, p. 63-71.

REYNARD E, PERRET A, BUSSARD J, GRANGIER L AND MARTIN S. 2016. Integrated approach for the inventory and management of geomorphological heritage at the regional scale. Geoheritage 8(1): 43-60.

RICCOMINI C AND TURCQ BJ. 2004. The Colonia Crater, a probable impact structure in southeastern Brazil. Meteoritics and Planetary Science 39(Suppl.): A88.

SÁNCHEZ JP. 2006. Mapeamento 1: 25000 do Núcleo do Astroblema Domo de Araguainha (MT) e aspectos Geoturísticos da Região. Trabalho de Conclusão de Curso, IGCE, UNESP, Rio Claro, 2006, 57 p.

SÁNCHEZ JP. 2014. Mapeamento geológico estrutural do Astroblema de Cerro do Jarau-brasil. PhD thesis. Universidade Estadual Paulista Júlio de Mesquita FilhoCampus de Rio Claro, Programa de Pós-graduação em Geologia Regional. Instituto de Geociências e Ciências Exatas. Rio Claro-São Paulo-Brasil, 189 p.

VASCONCELOS MAR, WUNNEMANN K, CRÓSTA AP, MOLINA EC, REIMOLD WU AND YOKOYAMA E. 2012. Insights into the morphology of the Serra da Cangalha impact structure from geophysical modeling. Meteor Plane Science 47(10): 1659-1670. 